DOI: 10.5604/01.3001.0009.5189

\title{
PROBLEMY WSPOMAGANIA DECYZJI W SYSTEMACH UTRZYMANIA RUCHU
}

\author{
Ewelina Kosicka ${ }^{1}$, Dariusz Mazurkiewicz ${ }^{1}$, Arkadiusz Gola ${ }^{2}$ \\ ${ }^{1}$ Politechnika Lubelska, Wydział Mechaniczny, Katedra Podstaw Inżynierii Produkcji; ${ }^{2}$ Politechnika Lubelska, Wydział Zarządzania, Katedra Organizacji Przedsiębiorstwa
}

Streszczenie. W artykule przedstawiono problemy zwiazane $z$ opracowaniem modelu adaptacyjnego algorytmu wspomagania decyzji $w$ systemie utrzymania ruchu, który $w$ zależności od zmieniajacych się parametrów procesów resztkowych, dobiera odpowiedni model matematyczny wyznaczony przez kryteria predykcyjne i informacyjne. Proponowany model zawiera dodatkowo część decyzyjna, która na podstawie informacji skupiajacych się na obszarze działań Stużb Utrzymania Ruchu generuje zawężony optymalny przedział czasu, w którym konieczne jest przeprowadzenie konserwacji.

Słowa kluczowe: predykcyjne utrzymanie ruchu, modele predykcyjne, awaria wyposażenia, diagnostyka uszkodzeń

\section{PROBLEMS OF DECISION SUPPORT IN MAINTENANCE SYSTEMS}

Abstract. The paper proposes problems with development of a model of adaptive algorithm for maintenance decision support system which - depending on the changing parameters of residual processes - selects an adequate mathematical model based on predictive and informative criteria. The proposed model additionally contains a maintenance decision-related part which - based on the information about actions taken by maintenance services generates a constrained optimal time interval for performing the necessary maintenance work.

Keywords: predictive maintenance, predictive models, equipment failure, fault diagnosis

\section{Wstęp}

Wysoki poziom skomplikowania procesów, a także wdrażanie nowoczesnych technologii wytwarzania, stawiają olbrzymie wymagania wobec niezawodności wyposażenia produkcyjnego. $\mathrm{Z}$ tego względu wzrasta znaczenie działań wykonywanych w ramach systemu utrzymania ruchu. Utrzymanie potencjału eksploatacyjnego wyposażenia produkcyjnego jest możliwe poprzez skuteczną kontrolę stanu technicznego maszyn i urządzeń. Szczególnie pożądana jest przy tym umiejętność przewidywania potencjalnych uszkodzeń poszczególnych obiektów technicznych wchodzących w skład systemu produkcyjnego oraz przywracania im pełnej sprawności w jak najkrótszym czasie - bez konsekwencji dla przebiegu procesu produkcyjnego. Możliwość przewidywania awarii na podstawie informacji dotyczącej stanu parku maszynowego jest podstawą predykcyjnego utrzymania ruchu.

Predykcyjne utrzymanie ruchu jest popularną strategią optymalnego użytkowania maszyn i urządzeń poprzez wyeliminowanie występowania awarii i optymalne planowanie prac serwisowych. Skuteczność tej strategii jest wysoce zależna od poziomu wiedzy Służb Utrzymania Ruchu (SUR) na poszczególnych etapach wdrożenia jej elementów. Podstawą do budowy prognoz są m.in. pomiary takich wielkości jak wibracje, temperatura, hałas czy chociażby informacje o układzie smarowania (m.in. ciśnienie, skład chemiczny smaru/oleju, właściwości fizyczne). Pomimo trudności wynikających również z konieczności konstruowania skomplikowanych zapytań do bazy danych, takie podejście pozwala skutecznie identyfikować rozwój procesów przyczyniających się do powstawania awarii.

\section{Rozwój strategii utrzymania ruchu}

Pomimo ciągłego doskonalenia wytwarzanych maszyn i urządzeń, które wynika $\mathrm{z}$ dynamicznie rozwijającej się automatyzacji, rozbudowanych systemów monitorowania, a także stale rosnących oczekiwań ze strony przemysłu, jednym z głównych obszarów zmagań przedsiębiorstw jest walka z występującymi awariami infrastruktury technicznej. Nieplanowane postoje wynikające $\mathrm{z}$ uszkodzenia maszyn czy urządzeń są źródłem strat finansowych spowodowanych niewykorzystaniem w pełni posiadanego sprzętu, kadry pracowniczej i występujących opóźnień terminów dostaw do kontrahentów.

O uciążliwości ich występowania, a także o odczuwalnych dla przedsiębiorstw konsekwencjach jakie za sobą niosą, może świadczyć chociażby fakt stałego dążenia do ich eliminacji poprzez rozwój strategii utrzymania ruchu. $\mathrm{Na}$ podstawie literatury $[1,5,10,18]$ opisującej ewolucję podejścia do prowadzonych przez Służby Utrzymania Ruchu działań, można wyróżnić trzy główne polityki eksploatacyjne (rys. 1):

- reakcyjne utrzymanie ruchu (ang. reactive maintenance),

- prewencyjne utrzymanie ruchu (ang. preventive maintenance),

- predykcyjne utrzymanie ruchu (ang. predictive maintenance).

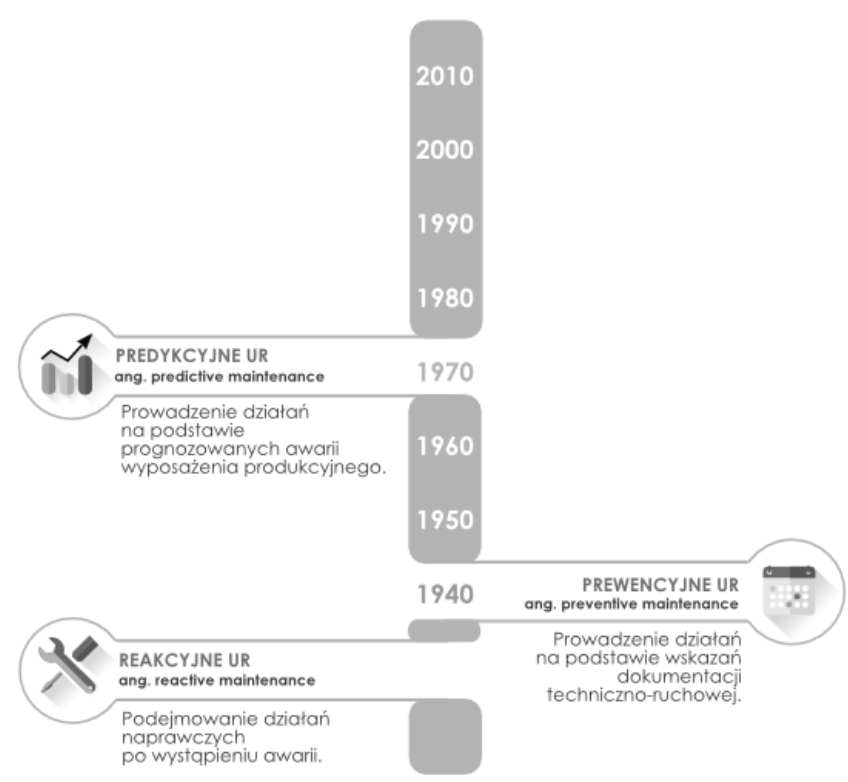

Rys. 1. Strategie utrzymania ruchu (opracowanie wlasne)

W dalszej części artykułu przedstawiono krótką charakterystykę każdej ze strategii.

\subsection{Reakcyjne utrzymanie ruchu}

Podejściem sięgającym początków w eksploatacji pierwszych maszyn i urządzeń jest reakcyjne utrzymanie ruchu [9]. Polega ono na podejmowaniu działań naprawczych po wystąpieniu awarii $[9,18]$. Tego typu podejście cechuje generowanie niskich kosztów ponoszonych na utrzymanie SUR oraz małe zapotrzebowanie na personel odpowiedzialny za naprawy w okresie bezawaryjnej pracy. 
Należy jednak przede wszystkim podkreślić negatywne konsekwencje wynikające $\mathrm{z}$ funkcjonowania $\mathrm{w}$ przedsiębiorstwie tego typu strategii. Wśród nich najczęściej wymienia się $[8,10,18]$ :

- dużą częstotliwość występowania awarii,

- wzrost kosztów napraw w wyniku bardziej rozległych awarii,

- wydłużony czas przywracania sprawności maszyn i urządzeń,

- brak możliwości planowania i harmonogramowania działań realizowanych przez SUR,

- brak możliwości opracowania budżetu przeznaczonego na działania SUR.

Ze względu na liczne wady reakcyjnego utrzymania ruchu obecnie odchodzi się od takiego podejścia, aczkolwiek nadal można spotkać przedsiębiorstwa podejmujące działania jedynie na zasadzie tzw. „gaszenia pożarów”. Ma to miejsce zazwyczaj $\mathrm{w}$ przedsiębiorstwach zajmujących się produkcją jednostkową i małoseryjną, w których to wystąpienie awarii nie powoduje znaczących trudności w przebiegu procesu produkcyjnego.

\subsection{Prewencyjne utrzymanie ruchu}

Rola niezawodnej pracy parku maszynowego w perspektywie utrzymywania wysokiego poziomu jakości wytwarzanych wyrobów oraz ograniczania występujących strat finansowych zainicjowała rozwój prewencyjnego utrzymania ruchu. Polega ono na prowadzeniu napraw i konserwacji infrastruktury technicznej $\mathrm{w}$ oparciu o zapisy pochodzące $\mathrm{z}$ dokumentacji technicznoruchowej.

Świadome nadzorowanie stanu technicznego maszyn i urządzeń szybko zyskało wielu zwolenników, zwłaszcza ze względu na korzyści osiągane $\mathrm{z}$ wdrożenia prewencyjnych działań konserwacyjno-naprawczych w porównaniu do wcześniejszej strategii. Entuzjazm związany $\mathrm{z}$ funkcjonowaniem Służb Utrzymania Ruchu w myśl takiej polityki eksploatacyjnej widoczny był zwłaszcza w przedsiębiorstwach zajmujących się produkcją masową, w których to konsekwencje awarii stanowią zagrożenie zarówno dla bezpieczeństwa, jak i terminowej realizacji produkcji. Chociaż prewencyjne utrzymanie ruchu nie daje gwarancji niewystępowania awarii, wymaga dużego zaangażowania personelu, a na dodatek prowadzone czynności konserwacyjne nie zawsze są związane $\mathrm{z}$ rzeczywistym stanem maszyn, to należy podkreślić liczne korzyści, jakie przedsiębiorstwa osiągają dzięki jego wdrożeniu.

Należą do nich między innymi [18]:

- wydłużenie czasu eksploatacji podzespołów maszyn i urządzeń,

- możliwość opracowania planów i harmonogramów działań wykonywanych przez SUR,

- planowanie budżetu przeznaczonego na działania realizowane przez SUR.

\subsection{Predykcyjne utrzymanie ruchu}

Rozwój technologii oraz automatyzacji dały szanse specjalistom od utrzymania ruchu na prowadzenie bardzie wnikliwych obserwacji stanu parku maszynowego. Rozbudowane systemy monitorowania parku maszynowego pozwoliły gromadzić dane dotyczące procesów resztkowych tj. wibracje, hałas czy temperatura, a te $\mathrm{z}$ kolei dały możliwość prowadzenia konserwacji na podstawie stawianych prognoz [1].

Predykcyjne utrzymanie ruchu (ang. predictive maintenance, $P d M)$ polega na prognozowaniu możliwości wystąpienia awari parku maszynowego przy wykorzystaniu zaimplementowanego modelu matematycznego. Na wdrożenie takiej strategii decydują się najczęściej przedsiębiorstwa, w których produkcja ma charakter masowy, a awarie niektórych z posiadanych maszyn stanowią zagrożenie dla bezpieczeństwa osób obsługujących, realizacji produkcji lub podwyższają koszty utrzymania ruchu.

Wśród problemów związanych z PdM należy wymienić konieczność doposażenia posiadanego parku maszynowego w sprzęt związany $\mathrm{z}$ monitorowaniem i diagnozą jego stanu technicznego, a także konieczność przeprowadzenia szkoleń dla pracowników. Ponoszone koszty inwestycyjne mogą stanowić dla kadry zarządzającej argument przemawiający za odrzuceniem wdrożenia PdM. Przedsiębiorstwa, które podjęły decyzję o prowadzeniu konserwacji w myśl predykcyjnego utrzymania ruchu, wskazują jednak na liczne korzyści, które osiągnęły dzięki podjętej decyzji dotyczącej zmiany prowadzonej strategii.

Wśród nich wymienia się najczęściej:

- zauważane zmniejszenie występowania awarii w porównaniu z systemem planowo-zapobiegawczym,

- wydłużenie czasu eksploatacji części maszyn i urządzeń,

- zmniejszenie wielkości następstw awarii,

- zmniejszenie kosztów związanych z częściami zamiennymi i robocizną,

- poprawa bezpieczeństwa pracy.

\section{Prognozowanie $w$ diagnostyce wielosymptomowej}

Prognozowanie awaryjności parku maszynowego w oparciu o zapisy pochodzące $\mathrm{z}$ systemu monitorowania stanowi cenne rozwiązanie z punktu widzenia Służb Utrzymania Ruchu, których zadaniem jest minimalizowanie liczby występujących awarii. Skuteczność strategii PdM uzależniona jest od poziomu wiedzy na poszczególnych etapach projektowania systemu predykcyjnego [5]. Wiele $\mathrm{z}$ dotychczas prowadzonych badań dotyczących testowania skuteczności modeli predykcyjnych na płaszczyźnie przewidywania awarii korzystało z obserwacji jednego symptomu (przykładem może być chociażby przypadek analizowania prędkość wibracji połączeń czołowych turbogeneratora, ze względu na ich częste uszkodzenia [19]).

Złożoność niektórych obiektów technicznych przemawia za koniecznością rozbudowania systemów prognostycznych $\mathrm{i}$ przejścia $\mathrm{z}$ prognozowania jednosymptomowego na wielosymptomowe [1]. Jest to istotne zwłaszcza w przypadku, gdy istnieje ryzyko rozwijania się wielu rodzajów uszkodzeń [17].

Prognozowanie w diagnostyce wielosymptomowej może przebiegać w oparciu o wiele modeli prognostycznych do generowania wielu niezależnych prognoz, jak i przy wykorzystaniu jednego modelu do jednoczesnego tworzenia wielu prognoz [16]. Schematy takich modeli prognostycznych zaprezentowano na rys. 2.

Dla przedstawionych modeli zbiór wielkości wejściowych może tworzyć miara eksploatacji obiektu bądź składowe wektora parametrów pracy, natomiast wielkościami wyjściowymi są prognozy wartości symptomu [16]. W przypadku pierwszego podejścia do modelowania prognoz (rys. 2a) istnieje możliwość stosowania dowolnych dostępnych metod prognostycznych, natomiast drugie podejście (rys. 2b) wymaga budowy niezależnego modelu. Prognozowanie wartości lub zmian zmiennych endogenicznych jest możliwe przy wykorzystaniu opracowanych metod prognostycznych. Ich dobór uzależniony jest od charakteru zmiennej prognozowanej [14].

\section{Problemy wspomagania decyzji w utrzymaniu ruchu}

$\mathrm{Z}$ racji stopnia zaawansowania samych modeli predykcyjnych, jak i ilości danych gromadzonych i poddawanych analizom (zbiory wartości parametrów stanu można określić mianem tzw. zbiorów big data). Opracowanie i wdrożenie systemu prognostycznego może tym samym stanowić wyzwanie dla przedsiębiorstw, zwłaszcza gdy na podstawie uzyskanych prognoz należy podejmować decyzje o prowadzeniu adekwatnych działań konserwacyjno-remontowych.

Należy zaznaczyć, iż stosowane rozwiązania $\mathrm{z}$ zakresu predykcji awarii, chociaż wykorzystują rzetelne dane zapisywane automatycznie z systemów monitorujących prace maszyn w czasie rzeczywistym, opierają się na prognozach budowanych bez 
uwzględnienia cech jakościowych i aspektów nietechnicznych $[2,3,5,6,7,11,15]$.

Uwzględnienie w modelu prognostycznym większej liczby czynników mających wpływ na awaryjność parku maszynowego otwiera możliwość na generowanie bardziej trafnych prognoz. Autorzy proponują zatem budowę modelu predykcyjnego w oparciu o następujące grupy danych:

1) dane pomiarowe:

a) procesy resztkowe,

b) warunki zewnętrzne;

2) dane dotyczące planów produkcji;

3) dane dotyczące obsługi.

W przypadku danych pomiarowych, należy przede wszystkim określić, które procesy resztkowe będą wystarczającym źródłem informacji o stanie obserwowanej części/podzespołu maszyny oraz które informacje dotyczące warunków zewnętrznych (np. temperatura na hali, stopień zapylenia) mają rzeczywisty wpływ na wystąpienie awarii.

a)

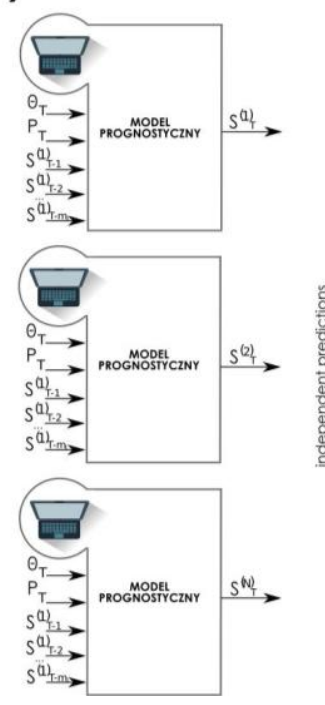

Rys. 2. Ogólne schematy modeli prognostycznych $w$ diagnostyce wielosymptomowej Podejście $z$ wykorzystaniem wielu modeli $i$ wielu niezależnych prognoz (a) oraz wykorzystanie jednego modelu (b) do tworzenia wielu prognoz jednocześnie ( $\Theta T$ - wartość miary eksploatacji, dla której tworzy się prognozę, PT - wektor parametrów sterujacych diagnozowanym obiektem dla chwili TST - wektor obserwacji symptomów określony $w$ chwili $t \quad[S(1) T, \quad S(2) T, \ldots, \quad S(m) T])$ (na podstawie[16])

Problemem może być przeprowadzenie redukcji wymiaru wektora obserwacji do podprzestrzeni o mniejszym wymiarze, która nie przyczyni się do utraty informacji wystarczających do poprawnego określenia stanu maszyny. Taka redukcja pozwala na zbudowanie prostszych i efektywniejszych modeli objaśnianych zjawisk. Konieczne będzie także określenie sposobu uwzględnienia ich oddziaływania na niezawodność parku maszynowego.

Druga grupa danych obejmuje informacje dotyczące planu produkcji. Dotyczą one m.in. planowanych przerw produkcyjnych, zmiany wydajności produkcji czy asortymentu i ilości wytwarzanych produktów. Podobnie jak w przypadku informacji z grupy pierwszej, tak i w tej grupie informacji należy wytypować odpowiednie kategorie wielkości mierzonych, które mają wpływ na prognozowanie awarii. Problematycznym jest również określenie stopnia ich wpływu na termin wystąpienia awarii.

$\mathrm{Na}$ awaryjność wpływa również sposób obsługi parku maszynowego - mowa tu chociażby o terminowej realizacji prac prewencyjnych czy o stopniu znajomości maszyn i urządzeń przez operatorów. W tym przypadku pojawia się kwestia określenia sposobu wyrażania wpływu czynnika ludzkiego oraz przede wszystkim opracowania metodyki gromadzenia danych i metody ich wyrażania. Źródłem takich informacji mógłby być system CMMS (ang. Computerised Maintenance Management Systems), którego zadaniem jest wspieranie działań realizowanych przez Dział Utrzymania Ruchu. Warunkiem wykorzystania informacji pochodzących $\mathrm{z}$ systemu CMMS do budowy modelu predykcyjnego jest jednak rzetelność wprowadzonych danych, zaangażowanie personelu $\mathrm{w}$ ciągłą aktualizację danych dotyczących pracowników oraz przeprowadzanie szkoleń mających na celu podnoszenie kwalifikacji operatorów.

Nie ujmowanie wymienionych czynników w stosowanych modelach predykcji awarii może wynikać $\mathrm{z}$ braku standardów ich wyrażania, zwłaszcza, że większość z nich z racji ich specyfiki opisu powinna być określona $\mathrm{w}$ formie lingwistycznej.

Aspektem mającym wpływ na dokładność i rzetelność stawianych prognoz jest ponadto starzenie się obserwowanego obiektu. Z przeprowadzonego przeglądu literatury $[7,8,10,17]$ wynika wniosek dotyczący istnienia silnego związku liczby uszkodzeń z czasem eksploatacji obiektu, jednak nie zauważono uwzględnienia tego faktu przy opracowywaniu prognoz dotyczących awaryjności maszyn i urządzen. Właściwe byłoby zatem budowanie prognozy i wnioskowanie o awaryjności również $\mathrm{w}$ funkcji zmian częstotliwości występowania awarii wynikającej z okresu eksploatacji.

Aby istniała możliwość uwzględnienia starzenia, konieczne byłoby posiadanie informacji o przebiegu procesu starzenia takiego samego elementu pracującego $\mathrm{w}$ podobnych warunkach eksploatacyjnych.

Dynamiczny charakter zmieniających się wartości parametrów, jak i specyfika funkcjonowania przedsiębiorstw narzuca sposób podejścia do budowy modelu prognostycznodecyzyjnego, który powinien również reagować w sposób dynamiczny na zmieniające się warunki produkcji. Mowa tu o stawianiu prognozy $i$ podejmowaniu decyzji natychmiast po otrzymaniu do systemu odczytu z systemów pomiarowych. Konieczne staje się zatem określenie liczby pomiarów na dobę, które będą gromadzone w systemach bazodanowych i przetwarzane przez odpowiednie algorytmy. Należy zadbać, aby nie dochodziło do przeładowania informacyjnego, ale aby również liczba pomiarów była wystarczająca do generowania wiarygodnych prognoz.

Proponowany model prognostyczno-decyzyjny w zależności od zmieniających się wartości procesów resztkowych stawiałby prognozę dotyczącą terminu potencjalnej awarii w oparciu o dopasowany model matematyczny (dla ciągu homoskedastycznego i heteroskedastycznego). Wybór odpowiedniego modelu byłby poparty wynikami kryteriów informacyjnych i predykcyjnych. Kolejnym problemem do rozwiązania jest zatem wybór tych kryteriów, które w najlepszy sposób będą wskazywały optymalny model, a także wybór odpowiedniego narzędzia, które na podstawie wyników kryteriów wybierze ów model.

Pozyskane wartości wejściowe dotyczące zarówno aspektów technicznych jak i nietechnicznych, a także cech jakościowych są potrzebne do wygenerowania samej prognozy. Ta dostarcza jedynie informację o tym, kiedy może nastąpić awaria maszyny. Aby wyznaczyć termin, w którym należy dokonać konserwacji, w procesie decyzyjnym należy uwzględnić informacje odnoszące się do planu produkcji, harmonogramu działań SUR oraz informacji dotyczących zamówienia części zamiennych. Takie wielokryterialne wspomaganie podejmowania decyzji wyłącza czynnik ludzki opierający się często na intuicji, a nie na danych pochodzących z procesu, jednak wymaga wdrażania do systemu prawdziwych danych. Jakiekolwiek zakłamane informacje, bądź brak wpisów będących danymi wejściowymi do modelu, wpłyną na wskazanie terminu przeprowadzenia konserwacji, który będzie kolidował $\mathrm{z}$ planem produkcyjnym i harmonogramem prac realizowanych przez SUR.

Wykorzystanie do generowania prognozy i podejmowania decyzji o czasie przeprowadzenia konserwacji tak wielu czynników, mających wpływ na niezawodność maszyn, daje bez wątpienia podstawę do budowy systemu ekspertowego, który zastąpi człowieka na etapie doboru metody predykcji w zależności od rodzaju parametrów wejściowych, jak i na etapie podjęcia decyzji o momencie realizacji działań naprawczych. Prawidłowe działanie takiego systemu prognostyczno-decyzyjny uzależnione jest przede wszystkim od sukcesu w rozwiązaniu postawionych problemów. 


\section{Podsumowanie i wnioski}

Opracowanie modelu predykcyjnego, generującego prognozy na podstawie wartości procesów resztkowych, cech jakościowych i aspektów nietechnicznych (tj. odczyty temperatury, amplitudy wibracji, komunikaty dotyczące obsługi maszyn), który dodatkowo będzie wspierał podejmowanie decyzji o momencie przeprowadzenia działań konserwacyjnych, pozwoli na generowanie dokładniejszych prognoz awaryjności parku maszynowego. Wpłynie to na wzrost poziomu wiedzy przedsiębiorców o stanie posiadanej infrastruktury technicznej, a także przyczyni się do przeprowadzania działań konserwacyjnych wynikających z rzeczywistego stanu monitorowanych części/podzespołów maszyn, a nie jak to odbywa się w większości przedsiębiorstw na podstawie zapisów wynikających z dokumentacji techniczno-ruchowej.

Wymienione w artykule problemy stają się punktem wyjścia do opracowania rozwiązań pozwalających $w$ dalszych etapach na realizację prac związanych $\mathrm{z}$ budową modelu predykcyjnodecyzyjnego. Pomimo trudności związanych $\mathrm{z}$ rozwiązaniem wspomnianych problemów, właściwym wydaje się być podejście skłaniające do podjęcia pracy związanej $\mathrm{z}$ uwzględnieniem wymienionych czynników w budowie prognoz awaryjności parku maszynowego, zwłaszcza w sytuacji, gdy dzięki temu opracowywane prognozy mogą być dokładniejsze, a podejmowane na ich podstawie decyzje bezapelacyjnie będą przynosić realne korzyści przedsiębiorstwom prowadzącym działalność produkcyjną.

\section{Literatura}

[1] Batko W.: Metody syntezy diagnoz predykcyjnych w diagnostyce technicznej Rozprawa habilitacyjna, AGH, Kraków 1984

[2] Cempel Cz.: Diagnostyka wibroakustyczna maszyn. PWN, Warszawa 1989.

[3] Fidali M.: Ultradźwięki w diagnostyce i eksploatacji łożysk tocznych. „Utrzymanie Ruchu” 1/2015, 56-61

[4] Grudziński J.: Koncepcja "e-maintenance" w systemie utrzymania ruchu maszyn i pojazdów rolniczych. Inżynieria Rolnicza, 4/2012, 205-2013, [DOI: 10.14654].

[5] Hetmańczyk M.: Predykcyjne utrzymanie ruchu. Inżynieria\&Utrzymanie Ruchu $1 / 2015,60-64$

[6] Kaźmierczak J.: Zastosowanie liniowych modeli procesów losowych do prognozowania w diagnostyce maszyn. Rozprawa habilitacyjna. Politechnika Śląska, Gliwice 1989.

[7] Legutko S.: Eksploatacja maszyn. Poznań. Wyd. Politechniki Poznańskiej, Poznań 2007.

[8] Legutko S.: Podstawy eksploatacji maszyn i urządzeń. Podręcznik. WSiP, Warszawa 2008.

[9] Legutko S.: Trendy rozwoju utrzymania ruchu urządzeń i maszyn. Eksploatacja i Niezawodnosc - Maintenance and Reliability 2/2009, 8-16, [DOI: 10.17531 ].

[10] Lipski J.: Diagnostyka procesów wytwarzania. Politechnika Lubelska, Lublin 2013.

[11] Lucifredi A., Mazzieri C., Rossi M.: Application of multiregressive linear models, dynamic kriging models and neural network models to predictive maintenance of hydroelectric power systems. Mechanical Systems and Signal Processing 14(3)/2000, 471-494.
[12] Piersiala S., Trzcieliński S.: Systemy utrzymania ruchu [w:] Koncepcje zarządzania systemami wytwórczymi, red. M. Fertsch, S. Trzcieliński, Instytut Inżynierii Zarządzania, Politechnika Poznańska, Poznań 2005.

[13] Słowiński B.: Wprowadzenie do nauki o technice. Politechnika Koszalińska, Koszalin 2007

[14] Sobczyk M.: Prognozowanie. Teoria, przykłady, zadania. Placet, Warszawa 2008

[15] Sobieski W.: Stanowisko laboratoryjne do badania zjawiska kawitacji metodą wibroakustyczną. Diagnostyka 32/2004, 37-42.

[16] Tabaszewski M.: Prognozowanie w wielosymptomowej diagnostyce maszyn. Wydawnictwo Politechniki Poznańskiej, Poznań 2010

[17] Tabaszewski M.; Wielosymptomowa, prognoza stanu i czasu do awarii z wykorzystaniem sieci neuronowych. Diagnostyka 2 (42)/2007, 43-48.

[18] Walczak M.: System utrzymania ruchu czynnikiem przewagi konkurencyjnej przedsiębiorstwa, [w:] Mikuła B. (red.): Historia i perspektywy nauk o zarządzaniu. Fundacja Uniwersytetu Ekonomicznego w Krakowie, Kraków 2012 .

[19] Wróblewski S., Bytnar A., Juszkiewicz P.: Predykcja czasu życia turbogeneratora na podstawie obserwacji trendu zmian poziomu wibracji. Prace Naukowe Instytutu Maszyn, Napędów i Pomiarów Elektrycznych Politechniki Wrocławskiej. Studia i Materiały, Poznań 23/2012, 268-273.

Mgr inż. Ewelina Kosicka

e-mail: e.kosicka@pollub.pl

Doktorantka Wydziału Mechanicznego Politechnik Lubelskiej, w którym od 2013 r. pracuje jako asystentka w Katedrze Podstaw Inżynierii Produkcji. Jej zainteresowania naukowe skupiają się w obszarze diagnostyki maszyn oraz predykcji awarii wyposażenia technicznego przedsiębiorstw produkcyjnych.

Dr hab. inż. Dariusz Mazurkiewicz, prof. PL e-mail: d.mazurkiewicz@pollub.pl

Pracownik Katedry Podstaw Inżynierii Produkcji, związany z Politechniką Lubelską od 1992 roku. Specjalność naukowa: diagnostyka techniczna, komputerowe wspomaganie prac inżynierskich, systemy inteligentne, systemy ekspertowe, technologie górnicze, systemy utrzymania ruchu.
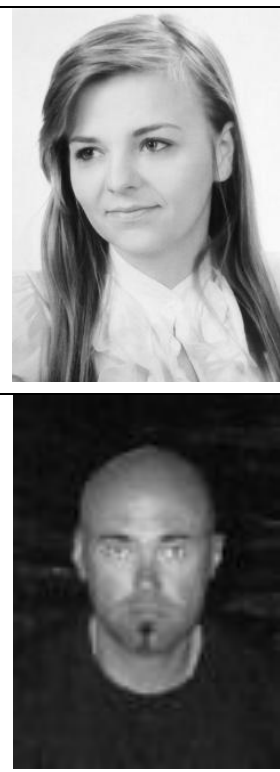

\section{Dr inż. Arkadiusz Gola}

e-mail: a.gola@pollub.pl

Pracownik naukowo-dydaktyczny w Katedrze Organizacji Przedsiębiorstwa Politechniki Lubelskiej. Jego zainteresowania naukowe obejmują problematykę organizacji produkcji oraz projektowania systemów produkcyjnych. Jest autorem lub współautorem kilkudziesięciu publikacji naukowych.

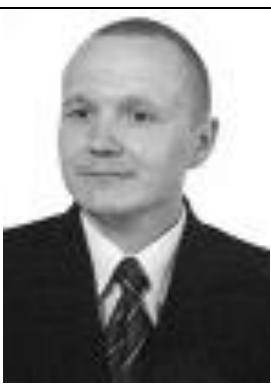

